\title{
Studies on the Experimental Variables Effects on Rhodium Catalyzed Hydroformylation of Unsaturated Fatty Esters and Comparison of $\left[\mathrm{RhH}(\mathrm{CO})\left(\mathrm{PPh}_{3}\right)_{3}\right]$ and $\left[\mathrm{RhCl}_{3} \cdot 3 \mathrm{H}_{2} \mathrm{O}\right]$ as Starting Catalytic Precursors
}

\author{
Ana N. F. Mendes, José R. Gregório and Ricardo G. da Rosa* \\ Instituto de Química, Universidade Federal do Rio Grande do Sul, Av. Bento Gonçalves, 9500, \\ 91501-970 Porto Alegre - RS, Brazil
}

\begin{abstract}
Reações de hidroformilação foram realizadas com oleato de metila grau técnico e óleo de soja usando $\left[\mathrm{RhH}(\mathrm{CO})\left(\mathrm{PPh}_{3}\right)_{3}\right]$ e $\left[\mathrm{RhCl}_{3} .3 \mathrm{H}_{2} \mathrm{O}\right]$ (ligação dupla/Rh = 745) como precursores catalíticos, modificados ou não por trifenilfosfina. O complexo $\left[\mathrm{RhH}(\mathrm{CO})\left(\mathrm{PPh}_{3}\right)_{3}\right]$ levou a $100 \%$ de conversão e $80-91 \%$ de produtos hidroformilados em $4 \mathrm{~h}$ para ambos substratos, sob condições reacionais brandas $\left(100{ }^{\circ} \mathrm{C}, 40 \mathrm{bar}, \mathrm{CO} / \mathrm{H}_{2}=2: 1\right.$, ligante/ $\left.\mathrm{Rh}=10: 1\right)$. Verificou-se a rápida isomerização do óleo de soja, produzindo isomeros trans e dienos conjugados, porém sem prejuízo à hidroformilação. A reação do óleo de soja com $\left[\mathrm{RhCl}_{3} \cdot 3 \mathrm{H}_{2} \mathrm{O}\right]$ puro, produz somente dienos conjugados, mas quando esse precursor foi modificado com trifenilfosfina (ligante/Rh $=10: 1$ ), nenhuma reação foi observada. Curiosamente, cristais amarelos correspondente ao complexo $\left[\mathrm{Rh}(\mathrm{Cl})(\mathrm{CO})\left(\mathrm{PPh}_{3}\right)_{2}\right]$ foram quantitativamente isolados ao final da reação.
\end{abstract}

Hydroformylation experiments were performed with technical-grade methyl oleate (MO) and soybean oil $(\mathrm{SO})$ using $\left[\mathrm{RhH}(\mathrm{CO})\left(\mathrm{PPh}_{3}\right)_{3}\right]$ and $\left[\mathrm{RhCl}_{3} \cdot 3 \mathrm{H}_{2} \mathrm{O}\right]($ double bond/Rh $=745)$ as catalyst precursors modified or not by triphenylphosphine. $\left[\mathrm{RhH}(\mathrm{CO})\left(\mathrm{PPh}_{3}\right)_{3}\right]$ shows $100 \%$ conversion and $80-91 \%$ selectivity to aldehydes in only $4 \mathrm{~h}$ for both substrates under mild conditions $\left(100^{\circ} \mathrm{C}\right.$, $40 \mathrm{bar}, \mathrm{CO} / \mathrm{H}_{2}=2: 1$, ligand/Rh $\left.=10: 1\right)$. Despite the rapid isomerisation of the soybean oil, producing trans isomers and conjugated dienes, no effects were observed on its further conversion to aldehydes. The reaction of soybean oil conducted with pure $\left[\mathrm{RhCl}_{3} .3 \mathrm{H}_{2} \mathrm{O}\right]$ produced only conjugated dienes, and when this precursor was modified with triphenylphosphine (ligand/Rh $=10: 1$ ) no reaction was observed at all. Curiously, yellow crystals corresponding to the complex $\left[\mathrm{Rh}(\mathrm{Cl})(\mathrm{CO})\left(\mathrm{PPh}_{3}\right)_{2}\right]$ were quantitatively isolated at the end of the reaction .

Keywords: soybean oil, methyl oleate, hydroformylation, rhodium

\section{Introduction}

World demand for ecologically correct and biodegradable products is on the rise. This motivates researchers to accomplish their work using vegetable oils and their derivatives in the synthesis of materials where they had once relied on petrochemical sources. ${ }^{1,2}$

The hydroformylation reaction, commonly known as the oxo process, is a useful way to chemically modify fatty acid esters and vegetable oils, thereby increasing their economic value. Moreover, the aldehydes produced are excellent raw materials which can be used in the formation of a plethora of compounds with applications in many areas such as lubricants, plasticizers, urethanes, and coatings. ${ }^{3,4}$ Hydroformylation can also be accomplished in the presence of many

*e-mail: rgomes@iq.ufrgs.br other functional groups like esters, amides, nitriles etc. and occurs with $100 \%$ atom economy. ${ }^{5,6}$ In the literature there are several works on the hydroformylation of unsaturated fatty esters and vegetable oils using mainly rhodium catalysts. Frankel ${ }^{7}$ reported a highly selective rhodium system for the hydroformylation of methyl oleate (MO) into methyl 9(10)-formylstearate, at 95-110 ${ }^{\circ} \mathrm{C}$ with a $1: 1$ mixture of $\mathrm{H}_{2}$ and $\mathrm{CO}$ at 500 to $2000 \mathrm{psi}$ (34.5 to 137.9 bar) with or without solvent. The rhodium catalyst, (5\% Rh supported on carbon, $\mathrm{CaCO}_{3}$ or $\mathrm{Al}_{2} \mathrm{O}_{3}$ ) in the presence of triphenylphosphine and under hydroformylation conditions, provided 90-99\% conversion to hydroformylated products. The same author reported the hydroformylation of methyl linoleate and methyl linolenate with a rhodium catalyst ( $5 \% \mathrm{Rh}$ supported on $\mathrm{Al}_{2} \mathrm{O}_{3}$ ) in the presence of triphenylphosphine. The reactions yielded 1,4-diformyl 
esters as major products and 1,3-diformyl esters as minor products. Unsaturated and saturated monoformyl esters were also produced from both substrates as well as triformyl esters from methyl linolenate. ${ }^{8}$

Muilwijk et al. ${ }^{3}$ reported a series of hydroformylation experiments performed with high-grade and technicalgrade MO and a rhodium catalyst modified by the bulky tris(2-tert-butyl-4-methylphenyl)phosphite. Under reaction conditions where $\mathrm{MO} / \mathrm{Rh}=910, \mathrm{~T}=80-100{ }^{\circ} \mathrm{C}$, $\mathrm{P}=20$ bar, $\mathrm{CO} / \mathrm{H}_{2}=1: 1$, with toluene as solvent, $95 \%$ conversion of pure MO was observed in $3 \mathrm{~h}$. The authors also noticed fast isomerization of the substrate to an olefin with a trans configuration that reacts slower than the original cis oleate. The use of technical-grade MO (containing 14\% of methyl linoleate, ML) results in lower reaction rates because dienes form stable $\pi$-allylic intermediates. More drastic conditions were required to obtain higher rates in the hydroformylation of technicalgrade $\mathrm{MO}\left(\mathrm{MO} / \mathrm{Rh}=910, \mathrm{~T}=50-120^{\circ} \mathrm{C}, \mathrm{P}=50-80 \mathrm{bar}\right.$, $\mathrm{CO} / \mathrm{H}_{2}=1: 1-1: 6$, toluene as solvent). Several ML isomers were also formed during the reaction. The hydroformylation of these isomers resulted in a complex mixture of products, in particular methyl formylstearates, methyl formyloleates and methyl diformylstearates.

In 2002, Kandanarachchi et al. reported the hydroformylation of vegetable oils (soybean, safflower, high oleic safflower and linseed) using $\left[\mathrm{Rh}(\mathrm{CO})_{2}(\mathrm{acac})\right]$ as catalyst precursor in the presence of $\mathrm{PPh}_{3}$ or $\mathrm{P}(\mathrm{OPh})_{3}{ }^{9}$ In this work, the authors observed a rhodium $\pi$-allyl complex formed from the catalyst and the diene (methyl linoleate), but they did not observe any significant effects of its formation on the reaction rate for vegetable oils.

First synthesized by Vaska in $1963^{10}$ and used five years later as catalyst in a hydroformylation reaction by Wilkinson, ${ }^{11}$ the complex $\left[\mathrm{RhH}(\mathrm{CO})\left(\mathrm{PPh}_{3}\right)_{3}\right]$ is one of the most active and studied precursors for the conversion of $\alpha$ olefins into aldehydes. ${ }^{12-15}$ However, to the best of our knowledge no systematic study on the hydroformylation of internal olefins such as fatty esters has been done before.

As catalytic and stoichiometric transformations of vegetable oils are the main aims of our laboratory, ${ }^{16-18}$ we decided to investigate the hydroformylation of technicalgrade methyl oleate and soybean oil with the complex $\left[\mathrm{RhH}(\mathrm{CO})\left(\mathrm{PPh}_{3}\right)_{3}\right]$.

Initially, we describe the $\left[\mathrm{RhH}(\mathrm{CO})\left(\mathrm{PPh}_{3}\right)_{3}\right]$ catalyzed hydroformylation of $\mathrm{MO}$ as a model for the subsequent hydroformylation of soybean oil (SO). We report on the effects of: reaction time, the presence of $\mathrm{PPh}_{3}$ as a modifier ligand and the $\mathrm{CO} / \mathrm{H}_{2}$ ratio. In addition, this $\mathrm{Rh}(\mathrm{I})$ preformed complex is compared with those generated in situ from $\left[\mathrm{RhCl}_{3} \cdot 3 \mathrm{H}_{2} \mathrm{O}\right]$ and $\mathrm{CO} / \mathrm{H}_{2}$, modified or unmodified by $\mathrm{PPh}_{3}$.
Concerning the substrates, both present similar reactivity for hydroformylation. However, $\left[\mathrm{RhH}(\mathrm{CO})\left(\mathrm{PPh}_{3}\right)_{3}\right]$ and $\left[\mathrm{RhCl}_{3} \cdot 3 \mathrm{H}_{2} \mathrm{O}\right]$ show a remarkably different catalytic performance.

\section{Experimental}

\section{Reagents}

$\left[\mathrm{RhCl}_{3} \cdot 3 \mathrm{H}_{2} \mathrm{O}\right]$ was purchased from Pressure Chemical and used as received. $\left[\mathrm{RhH}(\mathrm{CO})\left(\mathrm{PPh}_{3}\right)_{3}\right]$ was prepared according to a procedure described in the literature. ${ }^{19}$ Methyl Oleate (ACROS Organics, technical-grade, containing $c a .7 .5 \%$ of methyl linoleate) and Soybean Oil (Bunge) were used after filtration on neutral alumina to remove impurities, such as peroxides. Triphenylphosphine $\left(\mathrm{PPh}_{3}, 99 \%\right)$ was purchased from Alpha and used as received. The gases $\mathrm{H}_{2}$ (AGA, 99.999\%) and CO (Air Products, 99\%) were used as received.

\section{Equipment}

${ }^{1} \mathrm{H}$ and ${ }^{13} \mathrm{C}$ Nuclear Magnetic Resonance (NMR) spectra were obtained using a Varian VXR-200 $200 \mathrm{MHz}$ instrument. Chemical shifts were reported in ppm $(\delta)$ relative to tetramethylsilane (TMS), using $\mathrm{CDCl}_{3}$ as internal standard. FT-IR measurements were taken from thin films of liquid samples using $\mathrm{NaCl}$ windows in a Mattson-3020 FT-IR spectrometer. The appearance of a band at $2694 \mathrm{~cm}^{-1}$ indicates the presence of an aldehydic hydrogen. ${ }^{8}$

\section{Procedure}

The reactions were carried out in a glass-lined and magnetically stirred stainless-steel mini-reactor $(100 \mathrm{~mL})$ without solvent. In a typical reaction a mixture of $0.0218 \mathrm{~g}$ $(0.0238 \mathrm{mmol})$ of $\left[\mathrm{RhH}(\mathrm{CO})\left(\mathrm{PPh}_{3}\right)_{3}\right], 4.6768 \mathrm{~g}(17.7 \mathrm{mmol}$ of double bonds) of technical-grade methyl oleate (or $3.3024 \mathrm{~g}, 17.7 \mathrm{mmol}$ of double bonds, of soybean oil) and $0.0419 \mathrm{~g}(0.16 \mathrm{mmol})$ of $\mathrm{PPh}_{3}$, were charged into the reactor and sealed in. The sealed reactor was purged three times with hydrogen, pressurized with $\mathrm{CO}$ and $\mathrm{H}_{2}\left(40 \mathrm{bar}, \mathrm{CO} / \mathrm{H}_{2}\right.$ $=2$ ), and then heated in an oil bath with controlled temperature $\left(100{ }^{\circ} \mathrm{C}\right)$. At the end of the reaction time the mixture was cooled to room temperature and filtered on silica gel using dichloromethane as eluent. The samples were analyzed by ${ }^{1} \mathrm{H}$ NMR, ${ }^{13} \mathrm{C}$ NMR and FT-IR.

\section{Calculations}

The conversion and selectivity of the hydroformylation of soybean oil or methyl oleate samples were determined 
by ${ }^{1} \mathrm{H}$ NMR. The calculations are presented below using Figures 1-2 as examples.

\section{Determination of double bond number (DBN) for technical-grade methyl oleate}

The hydrogen signals were attributed according to the literature..$^{20}$ This attribution is shown in Figure 1.

We chose the signal corresponding to the methoxy group $(\delta 3.6)$ as the internal standard. So $1 / 3$ of its area was related to one hydrogen area which was taken as a normalization factor (NF) in all further calculations. As $A$ corresponds to the area of the olefinic hydrogens the double bond number is given by equation 1 .

$D B N_{M O}=\frac{A / 2}{N F}$

Applying this equation, the initial DBN value for the technical-grade $\mathrm{MO}$ is 1.12 .

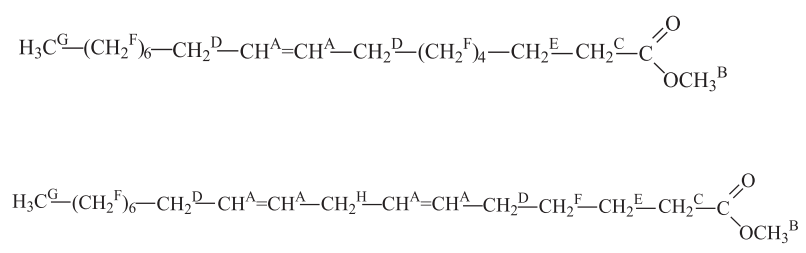

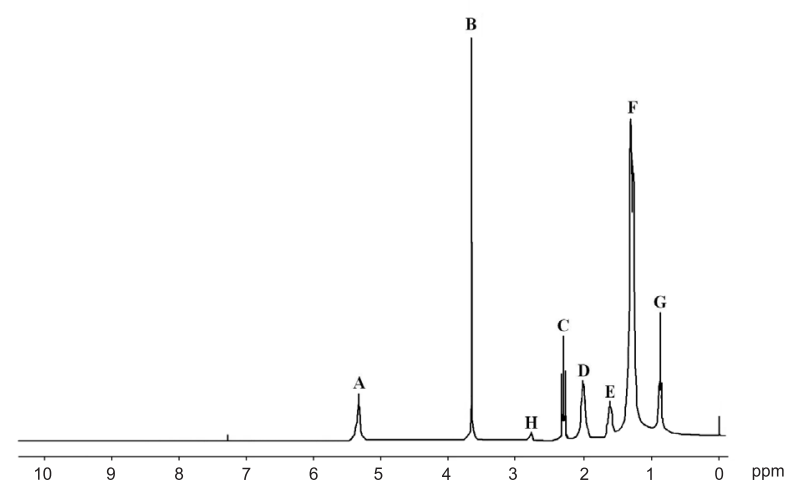

Figure 1. Technical-grade methyl oleate ${ }^{1} \mathrm{H}$ NMR.

\section{Determination of double bond number (DBN) for soybean oil}

The hydrogen signals were attributed according to the literature..$^{20}$ This attribution is shown in Figure 2.

For SO double bond number calculations, the signals corresponding to the terminal hydrogens of glycerol (4.1$4.3 \mathrm{ppm}$ ) were taken as the internal standard. Therefore, the area value related to one hydrogen is $1 / 4$ of the area integrated below these signals, which will be taken as a normalization factor (NF) in further calculations.

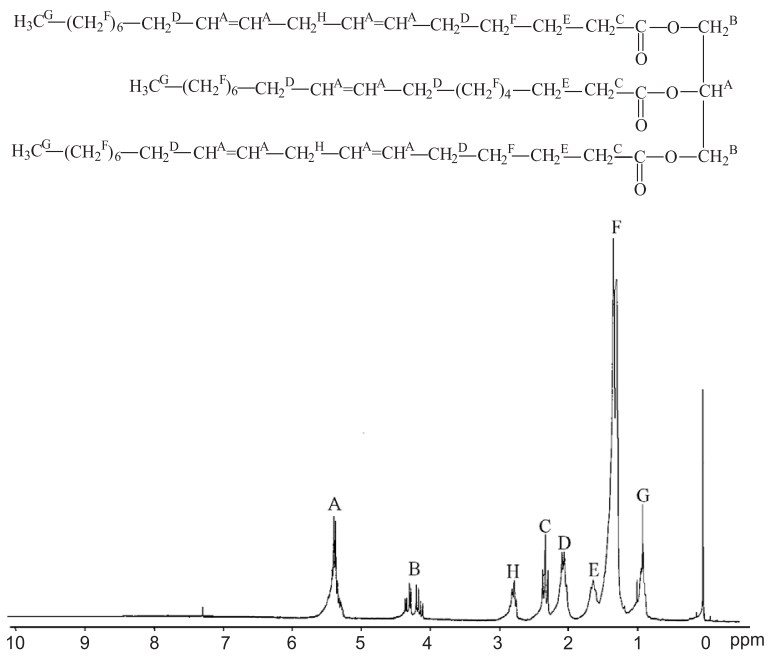

Figure 2. Soybean oil ${ }^{1} \mathrm{H}$ NMR.

According to Miyake, $A$ refers to the area of the two olefinic hydrogens plus the internal hydrogen of glycerol. This gives us equation 2 for the calculation of the double bond number for SO.

$D B N_{\text {SO }}=\frac{(A-N F) / 2}{N F}$

This equation is also applied in the calculation of $D B N$ after the hydroformylation procedure. The initial $D B N$ value calculated for the $\mathrm{SO}$ is 4.1 .

\section{Conversion}

To calculate the conversion for both substrates it is just necessary to know the relative amount of double bonds that disappeared:

Conversion $(\%)=\frac{D B N_{i}-D B N_{f}}{D B N_{i}} \times 100$

where $D B N_{i}$ is the initial double bond number and $D B N_{f}$ is the final double bond number.

\section{Selectivity}

For the calculation of selectivity in hydroformylation we need to correlate the normalized area of the aldehydic hydrogen $(J$, at $\delta 9.5)$ with respect to the double bonds consumed as stated by equation (4). In the case of selectivity in isomerisation, evaluated in terms of double bond conjugation and quantified by the integration of the signals $M$ at $\delta 5.5-6.4,{ }^{21}$ the same equation (4) is applied replacing $J$ by $M$.

Selectivity $(\%)=\frac{J / N F}{D B N_{i}-D B N_{f}} \times 100$ 


\section{Results and Discussion}

Attempting to perform the reactions under mild conditions, we decided to start using 20 bar of total pressure $\left(\mathrm{CO} / \mathrm{H}_{2}=1\right)$ for both substrates. However, this resulted in very poor reproductibility that should be related to kinetic and/or diffusion problems. Increasing the total pressure to 40 bar we then had excellent reproductibility considering the typical error of an NMR experiment ( $c a$. 10\%). This observation confirms our assumption about the importance of the diffusion effects. The results of the hydroformylation of methyl oleate with $\left[\mathrm{RhH}(\mathrm{CO})\left(\mathrm{PPh}_{3}\right)_{3}\right]$ are presented in Table 1. All entries in Table 1 are presented as average values for at least two reactions. In all cases the only products observed were those arisen from hydroformylation and hydrogenation.

\section{Effect of reaction time and addition of triphenylphosphine}

Analyzing the results of Table 1, we see that for 24h of reaction time (entry 1) $100 \%$ of conversion is attained along with $55 \%$ selectivity for hydroformylation. For $6 \mathrm{~h}$ of reaction time (entry 2) the conversion drops to $69 \%$ but the selectivity remains almost the same. Upon addition of an excess of $\mathrm{PPh}_{3}$ $\left(\mathrm{PPh}_{3} / \mathrm{Rh}=10\right.$, entry 3$)$ the activity of the catalytic system rises 4 times (see TOF numbers) with respect to entry 1 but maintains the same selectivity. This means that phosphine plays an important role in the stabilization of the same active species initially generated from the catalyst precursor.

\section{Effect of $\mathrm{CO} / \mathrm{H}_{2}$ ratio}

A twofold excess of $\mathrm{CO}$ over $\mathrm{H}_{2}$ was used to reduce the hydrogenation. Comparing entry 4 to entry 1 , no effect can be observed either on conversion or on selectivity. On the other hand, comparing entry 5 to entry 2 we find a significant change in the conversion rate, but the selectivity is still not affected. The combined effects of an excess of $\mathrm{CO}$ and phosphine led to the best results (entries 6 and 7) in terms of conversion and selectivity to hydroformylation.

Those results allow us to define the model conditions for the hydroformylation of $\mathrm{MO}$ as $40 \mathrm{bar}, \mathrm{CO} / \mathrm{H}_{2}=2,100$ ${ }^{\circ} \mathrm{C}, \mathrm{PPh}_{3} / \mathrm{Rh}=10$ and $\mathrm{t}=6 \mathrm{~h}$. The results for the hydroformylation of a real sample of soybean oil applying these conditions are summarized in Table 2. Besides hydroformylated and isomerized soybean oil, the only other product observed was hydrogenated SO.

The optimized conditions for MO, when applied to $\mathrm{SO}$, gave the same quantitative results (entry 1 ) supporting our assumption that the former would behave well as a model molecule.

In order to check out the catalytic activity, the reaction time was reduced from $6 \mathrm{~h}$ to $4 \mathrm{~h}$ and $2 \mathrm{~h}$ (entries 2 and 3 , respectively). With a $4 \mathrm{~h}$ reaction time same performance as in $6 \mathrm{~h}$ was attained, although with a $2 \mathrm{~h}$ reaction time conversion and selectivity of the hydroformylation dropped. It is interesting to note that when conversion was not complete we observed double bond isomerisation, as noticed by Larock, ${ }^{21}$ confirming that it occurs faster than hydroformylation. The isomerisations, which mean double bond conjugation, could represent a problem for the catalytic activity because conjugated dienes in the presence of transition metal hydrides should form very stable $\pi$-allylic complexes. ${ }^{3,9,22}$ The results presented in Table 2 (entries 1-3) show that this is not the case, since the conjugated products are readily converted to aldehydes. Also, the similar performance shown by the catalytic system in the presence of the monoinsaturated MO and the polyinsaturated SO may be taken as another piece of evidence demonstrating the aptitude of the rhodium allylic intermediates as active species for the hydroformylation. Triphenylphosphine excess had no effect on conversion (entries 2 and 4-6). An attempt to perform the reaction starting from pure $\left[\mathrm{RhCl}_{3} \cdot 3 \mathrm{H}_{2} \mathrm{O}\right]$ as catalyst (entry 7) led to only double bond conjugation and very low conversion. No catalytically active species

Table 1. Hydroformylation of technical-grade methyl oleate

\begin{tabular}{|c|c|c|c|c|c|}
\hline Entry & time $(\mathrm{h})$ & Conversion $(\%)$ & Hydroformylation (\%) & Yield $^{\mathrm{b}}(\%)$ & $\operatorname{TOF}^{b}\left(h^{-1}\right)$ \\
\hline 1 & 24 & 100 & 55 & 55 & 31 \\
\hline 2 & 6 & 69 & 52 & 36 & 86 \\
\hline $3^{c}$ & 6 & 100 & 53 & 53 & 124 \\
\hline $4^{\mathrm{d}}$ & 24 & 100 & 57 & 57 & 31 \\
\hline $5^{\mathrm{d}}$ & 6 & 90 & 50 & 46 & 112 \\
\hline $6^{\mathrm{c}, \mathrm{d}}$ & 24 & 100 & 81 & 81 & 31 \\
\hline $7^{\mathrm{c}, \mathrm{d}}$ & 6 & 100 & 90 & 90 & 124 \\
\hline
\end{tabular}

${ }^{\mathrm{a}}\left[\mathrm{RhH}(\mathrm{CO})\left(\mathrm{PPh}_{3}\right)_{3}\right]=0.0238 \mathrm{mmol}$; double bonds $=17.7 \mathrm{mmol} ; 100^{\circ} \mathrm{C} ; 40 \mathrm{bar} ; \mathrm{CO} / \mathrm{H}_{2}=1 ;{ }^{\mathrm{b}}$ Yield $=$ Hydroformylation $\mathrm{x}$ Conversion; $\mathrm{TOF}=\mathrm{mols}$ of double bond converted/(mols of rhodium . time); ${ }^{\mathrm{c}} \mathrm{PPh}_{3} / \mathrm{Rh}=10: 1$ (sevenfold excess of $\mathrm{PPh}_{3}$ added); ${ }^{\mathrm{d}} \mathrm{CO} / \mathrm{H}_{2}=2$. 
Table 2. Hydroformylation of soybean oil ${ }^{\mathrm{a}}$

\begin{tabular}{|c|c|c|c|c|c|c|c|}
\hline Entry & time (h) & $\mathrm{PPh}_{3} / \mathrm{Rh}$ & Conv. $(\%)$ & Hydrof.(\%) & Yield $^{\mathrm{b}}(\%)$ & Isom.(\%) & $\operatorname{TOF}^{\mathrm{b}}\left(\mathrm{h}^{-1}\right)$ \\
\hline 1 & 6 & 10 & 100 & 87 & 87 & 0 & 122 \\
\hline 2 & 4 & 10 & 100 & 86 & 86 & 0 & 182 \\
\hline 3 & 2 & 10 & 73 & 72 & 53 & 20 & 266 \\
\hline 4 & 4 & 7 & 96 & 75 & 73 & 0 & 174 \\
\hline 5 & 4 & 5 & 98 & 74 & 73 & 0 & 179 \\
\hline 6 & 4 & 15 & 96 & 78 & 76 & 0 & 174 \\
\hline $7^{\mathrm{c}}$ & 4 & 0 & 26 & 0 & 0 & 100 & 47 \\
\hline $8^{c}$ & 4 & 10 & 0 & 0 & 0 & 0 & 0 \\
\hline $9^{\mathrm{d}}$ & 4 & 10 & trace & nd & $\mathrm{nd}$ & $\mathrm{nd}$ & $\mathrm{nd}$ \\
\hline $10^{\mathrm{a}, \mathrm{e}}$ & 4 & 10 & 97 & 70 & 68 & 0 & 175 \\
\hline $11^{\mathrm{a}, \mathrm{e}}$ & 2 & 10 & 82 & 71 & 58 & 20 & 298 \\
\hline
\end{tabular}

${ }^{\mathrm{a}}\left[\mathrm{RhH}(\mathrm{CO})\left(\mathrm{PPh}_{3}\right)_{3}\right]=0.0238 \mathrm{mmol}$; Double bonds $=17.7 \mathrm{mmol} ; 100^{\circ} \mathrm{C} ; 40 \mathrm{bar} ; \mathrm{CO} / \mathrm{H}_{2}=2$; ${ }^{\mathrm{b}}$ Yield $=$ Hydroformylation $\mathrm{x}$ Conversion; $\mathrm{TOF}=\mathrm{mols}$ of double bond converted/(mols of rhodium $\times$ time); ${ }^{\mathrm{c}}\left[\mathrm{RhCl}_{3} \cdot 3 \mathrm{H}_{2} \mathrm{O}\right]$ as catalyst precursor; ${ }^{\mathrm{d}}\left[\mathrm{RhCl}(\mathrm{CO})\left(\mathrm{PPh}_{3}\right)_{2}\right]$ as catalyst precursor. ${ }^{\mathrm{e}} \mathrm{Reaction}$ performed with substrate obtained in entry 7.

are formed from $\left[\mathrm{RhCl}_{3} \cdot 3 \mathrm{H}_{2} \mathrm{O}\right]$ in the presence of $\mathrm{PPh}_{3}$ (entry 8 ), since no reaction was observed. Instead, yellow crystals characterized by $\mathrm{FT}^{-\mathrm{IR}^{23}}$ and showing the same spectrum of the complex $\left[\mathrm{Rh}(\mathrm{Cl})(\mathrm{CO})\left(\mathrm{PPh}_{3}\right)_{2}\right]$ were quantitatively isolated at the end of reaction time. Entry 9 proves the unexpected inertness of $\left[\mathrm{Rh}(\mathrm{Cl})(\mathrm{CO})\left(\mathrm{PPh}_{3}\right)_{2}\right]$ as a catalyst precursor, with very low conversion. ${ }^{24}$

Entries 10 and 11 were run in order to prove that conjugated $\mathrm{SO}$ is also an active substrate for the hydroformylation reaction. We performed the reactions under the same conditions as in reactions 2-3, starting with SO previously conjugated with $\left[\mathrm{RhCl}_{3} \cdot 3 \mathrm{H}_{2} \mathrm{O}\right]$ (entry 7). As expected, considering the NMR error, conjugated $\mathrm{SO}$ is as suitable as ordinary SO for hydroformylation, thus proving that the allyl-rhodium intermediates probably formed do not affect the catalytic activity.

\section{Conclusions}

$\left[\mathrm{RhH}(\mathrm{CO})\left(\mathrm{PPh}_{3}\right)_{3}\right]$ proved to be a suitable catalyst for the hydroformylation of $\mathrm{MO}$ and $\mathrm{SO}$. We have been able to achieve very good results in $4 \mathrm{~h}$, obtaining almost totally hydroformylated oils. The use of an excess of $\mathrm{PPh}_{3}$ over $\mathrm{Rh}$ (10:1) and $\mathrm{CO}$ over $\mathrm{H}_{2}$ (2:1) simultaneously proved to increase both conversion and selectivity. However, individually neither $\mathrm{PPh}_{3}$ nor $\mathrm{CO}$ in excess has any significant effect on catalysis. $\left[\mathrm{RhCl}_{3} \cdot 3 \mathrm{H}_{2} \mathrm{O}\right]$ does not catalyze hydroformylation although it causes some double bond isomerisation (conjugation). In the presence of $\mathrm{CO}, \mathrm{H}_{2}$ and $\mathrm{PPh}_{3}$, $\left[\mathrm{RhCl}_{3} \cdot 3 \mathrm{H}_{2} \mathrm{O}\right]$ quantitatively forms inactive $\left[\mathrm{Rh}(\mathrm{Cl})(\mathrm{CO})\left(\mathrm{PPh}_{3}\right)_{2}\right]$ instead of the catalytic active species. Conjugation of the double bonds of SO occurs during the reaction, but does not affect either reaction rate or selectivity.

\section{Acknowledgments}

A. N. F. Mendes thanks CAPES-Brazil for a fellowship.

\section{References}

1. Mol, J.C.; Green Chem. 2002, 4, 5.

2. Barnwal, B.K.; Sharma, M.P.; Renew. Sust. Energ. Rev. 2004, 1.

3. Muilwijk, K.F.; Kamer, P.C.J.; van Leeuwen, P.W.N.M.; J. Am. Oil Chem. Soc. 1997, 74, 223.

4. Guo, A.; Demydov, D.; Zhang, W.; Petrovic, Z.; J. Polym. Environ. 2002, 10, 49.

5. Trost, B.M.; Angew. Chem. Int. Ed. Engl. 1995, 34, 259.

6. Dupont, J.; Quim. Nova 2000, 23, 825.

7. Frankel, E.N.; J. Am. Oil Chem. Soc. 1971, 48, 248.

8. Frankel, E.N.; Thomas, F.L.; Rohwedder, W.K.; Ind. Eng. Chem. Prod. Res. Develop. 1973, 12, 47.

9. Kandanarachchi, P.; Guo, A.; Petrovic, Z.; J. Mol. Catal. A: Chem. 2002, 184, 65.

10. Bath, S.S.; Vaska, L.; J. Am. Chem. Soc. 1963, 85, 3500.

11. Evans D.; Yagupsky, G.; Wilkinson, G.; J. Chem. Soc. (A) 1968, 2660.

12. Mukhopadhyay, K.; Mandale, A.B.; Chaudhari, R.V.; Chem. Mater. 2003, 15, 1766.

13. Bianchini, C.; Lee, H.M.; Meli, A.; Vizza, F.; Organometallics 2000, 19, 849 .

14. Bhanage, B.M.; Divekar, S.S.; Deshpande, R.M.; Chaudhari, R.V.; J. Mol. Catal. A: Chem. 1997, 115, 247. 
15. Deshpande, R.M.; Divekar, S.S.; Gholap, R.V.; Chaudhari, R.V.; J. Mol. Catal. 1991, 67, 333.

16. Gerbase, A.E.; Brasil, M.C.; Gregório, J.R.; Mendes, A.N.F.; von Holleben, M.L.A.; Martinelli, M.; Grasas y Aceites 2002, $53,175$.

17. Gerbase, A.E.; Gregório, J.R.; Martinelli, M.; Brasil, M.C.; Mendes, A.N.F.; J. Am. Oil Chem. Soc. 2002, 79, 179.

18. Mendes, A.N.F.; da Rosa, R.G.; Gregório, J.R.; Brazilian pat. Br PI 0.401.450-2, 2004.

19. Osborn, J.A.; Wilkinson, G.; Inorg. Synth. 1990, $28,82$.

20. Miyake, Y.; Yokomizo, K.; Matsuzaki, N.; J. Am. Oil Chem. Soc. 1998, 75, 1091.
21. Larock, R.C.; Dong, X.; Chung, S.; Reddy, C.K.; Ehlers, L.E.; J. Am. Oil Chem. Soc. 2001, 78, 447.

22. van Leeuwen, P. W. N. M.; Roobeek, C. F.; J. Mol. Catal. 1985, 31, 345 .

23. Steele, D.F.; Stephenson, T.A.; J. Chem. Soc. Dalton 1972, 2161.

24. $\left[\mathrm{RhCl}(\mathrm{CO})\left(\mathrm{PPh}_{3}\right)_{2}\right]$ has shown to act as a catalyst for the hydroformylation of olefins and acetylenes under mild conditions as stated by Osborn, J.A.; Wilkinson, G.; Young, J.F.; Chem. Commun. 1965, 17 and Osborn, J.A.; Wilkinson, G.; Young, J.F.; Jardine, F.H.; Chem. Ind., 1965, 560.

Received: November 6, 2004 Published on the web: September 15, 2005 